\title{
Active strike-slip faulting in the Chablais area (NW Alps) from earthquake focal mechanisms and relative locations
}

\author{
Journal Article \\ Author(s): \\ Delacou, Bastien; Deichmann, Nicholas; Sue, Christian; Thouvenot, Francois; Champagnac, Jean-Daniel; Burkhard, Martin \\ Publication date: \\ 2005-08 \\ Permanent link: \\ https://doi.org/10.3929/ethz-b-000035105
}

Rights / license:

In Copyright - Non-Commercial Use Permitted

Originally published in:

Eclogae Geologicae Helvetiae 98(2), https://doi.org/10.1007/s00015-005-1159-4 


\title{
Active strike-slip faulting in the Chablais area (NW Alps) from earthquake focal mechanisms and relative locations
}

\author{
Bastien Delacou ${ }^{1}$, Nicholas Deichmann $^{2}$, Christian Sue $^{1}$, FrançOis Thouvenot $^{3}$, \\ JEAN-DANIEL ChAMPAGNAC ${ }^{1} \&$ MARTIN BuRKHARD ${ }^{1}$
}

Key words: Western Alps, Chablais, Prealpes, seismotectonics, relative location, active faulting

\begin{abstract}
The Chablais area is characterized by a complex geological setting, resulting from the transport of nappes of various internal origins (the Prealpine nappes), thrusted in Oligocene times onto the Helvetic cover of the external zones of the Alps. While the structural setting and timing of nappe emplacement are well understood, current tectonics and associated faulting remain unclear. The detailed analysis of the Bonnevaux and Samoëns earthquakes, presented in this study, constitutes a significant contribution to the active tectonics of the Chablais area. The associated seismotectonic regime appears to be constant with depth, both focal mechanisms yielding a strike-slip regime, one in the crystalline basement at around $17 \mathrm{~km}$ depth and the other probably cross-cutting the cover/basement interface at around $5 \mathrm{~km}$ depth. Relative location techniques, applied in this study to the seismic sequence associated to the Samoëns earthquake, represents the best way to identify active faults in a region where neotectonic evidence is scarce and controversial. The resulting seismic alignment corresponds to the $\mathrm{E}-\mathrm{W}$ oriented nodal plane inferred from the Samoëns main shock focal mechanism, thus defining an active near vertical E-W dextral fault. This strike-slip regime, compared to the current regional stress field, corresponds to the one observed in the Jura/Molasse basin area but contrasts with the exclusively dextral and NE-SW-oriented transcurrent regime of the Wildhorn/Martigny region.
\end{abstract}

\section{RESUME}

La région du Chablais est caractérisée par une configuration géologique et structurale complexe, résultant de la mise en place de nappes de charriage de provenances variées (nappes Préalpines) chevauchantes sur les unités externes Helvétiques durant l'Oligocène. Alors que l'historique de la mise en place de ces nappes est bien compris, le régime tectonique actuel reste à définir. L'analyse détaillée des séismes de Bonnevaux et de Samoëns présentées dans cette étude donne une bonne image du régime tectonique actuel de cette région. Le régime sismotectonique associé à ces séismes apparaît stable en fonction de la profondeur, de type décrochant, l'un au niveau du socle cristallin $(17 \mathrm{~km}$ de profondeur), l'autre intersectant probablement l'interface socle/couverture (5 $\mathrm{km}$ de profondeur). Les techniques de relocalisations relatives, appliquées dans cette étude dans le domaine temporel sur la séquence sismique associée au choc de Samoëns, représentent le meilleur, si ce n'est l'unique, moyen d'identifié des failles actives dans une région où les indices néotectoniques sont rares et controversés. L'alignement sismique ainsi défini correspond au plan nodal E-W du mécanisme au foyer du choc principal, permettant de définir une faille dextre, subverticale, orientée E-W. Ce régime décrochant, replacé dans son contexte tectonique régional, correspond à celui observé dans la région Jura/Plateau Molassique, caractérisé par un système de décrochements conjugués (dextre orienté E-W, sénestre orienté NW-SE) et contraste avec celui exclusivement dextre, orienté NE-SW, observé au niveau de l'alignement Wildhorn/Martigny.

\section{ZUSAMMENFASSUNG}

Das Chablaisgebiet zeichnet sich durch einen komplexen geologischen Aufbau aus, welcher Resultat des Transportes eines aus Einheiten unterschiedlicher interner Herkunft aufgebauten Deckenstapels (die voralpinen Decken) ist, der im Oligozän über die helvetische Bedeckung der externen Zone des Alpenbogens geschoben wurde. Während strukturgeologischer Aufbau und zeitlicher Ablauf der tektonischen Bewegungen relativ gut bekannt sind, bleiben die tatsächlichen Verschiebungen und die damit verbundene Bruchtektonik weitgehend unklar. Die in der vorliegenden Studie im Detail untersuchten Erdbeben von Bonnevaux und Samoëns ergeben ein ziemlich genaues Bild der aktiven Tektonik im Gebiet des Chablais. Das damit verbundene seismotektonische Regime erscheint in Abhängigkeit der Tiefe konstant. Die Herdmechanismen beider Erdbeben deuten auf ein Blattverschiebungsregime hin, wobei eines im kristallinen Sockel in ca. $17 \mathrm{~km}$ Tiefe lokalisiert wurde und das andere höchstwahrscheinlich die Übergangsszone zwischen Bedeckung und Sockel in ca. 5 $\mathrm{km}$ Tiefe überschneidet. Die in dieser Studie angewendeten relativen Lokalisierungstechniken (in der Zeitdomäne) für die seismische Sequenz des Samoëns-Erdbebens repräsentieren den besten (wenn nicht den einzigen) Ansatz zur Identifizierung aktiver Brüche in einer Region in welcher neotektonische Indizien spärlich vorhanden und kontrovers sind. Die Ausrichtung der daraus resultierenden seismischen Linie ist in guter Übereinstimmung zu der dextralen E-W orientierten Verwerfung, welche dem Herdmechanismus entnommen werden kann. Dieses Regime ist gut mit dem regionalen Stressfeld und der aktiven Tektonik im Gebiet Jura/Molassebecken vergleichbar, unterscheidet sich aber deutlich vom rein dextralen NE-SW gerichteten Blattverschiebungsregime im Gebiet Wildhorn/Martigny.

\footnotetext{
${ }^{1}$ Institut de Géologie, Université de Neuchâtel, rue Emile Argand 11, CP-2, CH-2007 Neuchâtel, Switzerland. E-mail: bastien.delacou@unine.ch

${ }^{2}$ Swiss Seismological Service, ETH-Zûrich, CH-8093 Zürich, Switzerland.

${ }^{3}$ Laboratoire de Géophysique Interne et Tectonophysique (LGIT), Maison des Géosciences, CNRS/UJF, Campus Universitaire, 1381 rue de la Piscine, BP 53 , FR-38041 Grenoble Cedex 1, France.
} 


\section{Introduction and tectonic setting}

The Chablais area is part of the Prealpine nappe system, which consists of a complex stack of sedimentary nappes of various internal origin (Valaisan, sub-Briançonnais, Briançonnais and Piemontais), metamorphosed into anchizonal to greenschist facies (Mosar 1988) at around 27 Ma (Jaboyedoff \& Cosca 1999). This nappe system was detached from its crystalline substratum in Oligocene times and thrust onto more external units consisting of the autochthonous sedimentary cover of the external massifs, the Helvetic nappes and the Subalpine Molasse (Schardt 1894; Schardt 1898; Escher et al. 1997; Mosar 1997; Mosar 1999; Borel \& Mosar 2000; Wissing \& Pfiffner 2002). The nappe stack, approximately $2 \mathrm{~km}$ thick, can be subdivided into 4 different nappes, depending on their paleogeographic origin and tectonic imbrication (Fig. 1). From external to internal, one can distinguish the Ultrahelvetic nappe, the Klippen nappe, the Breccia nappe and the "Nappe Supérieure"; the latter is subdivided into the Voirons and Simme nappes. The structural setting of the Prealps is dominated by kilometerscale folds and imbricate structures (Mosar et al. 1996; Mosar
1997; Wissing \& Pfiffner 2002), with a top-NW transport direction, controlled by a thick evaporite detachment layer of Triassic (Carnian) age in the "Préalpes Médianes Plastiques" and at the base of the middle Trias in the "Préalpes Médianes Rigides" (Baud 1972). For macrotectonic reasons, the Klippen nappe is classically divided in two parts (Lugeon \& Gagnebin 1941): the fold-dominated "Préalpes Médianes Plastiques" in the northwest, and the large imbricate structure of the "Préalpes Médianes Rigides" in the southeast. The Breccia nappe is disharmonically folded with respect to the Klippen nappe, implying an early phase of folding, prior to nappe emplacement (Wissing \& Pfiffner 2002). Underneath the Prealpine nappe stack, the autochthonous and allochthonous (Morcles nappe) Helvetic cover was folded and thrust in a NW direction under anchizonal conditions during Oligo-Miocene times (Burkhard \& Sommaruga 1998). Finally, the crystalline basement was affected by large-scale buckling and uplifted in Miocene times, forming the External Crystalline Massifs (ECM) of the Mont-Blanc and Aar massifs (Burkhard 1986).

While tectonic setting and structural evolution of the Prealps are relatively well-known, the current activity remains un-

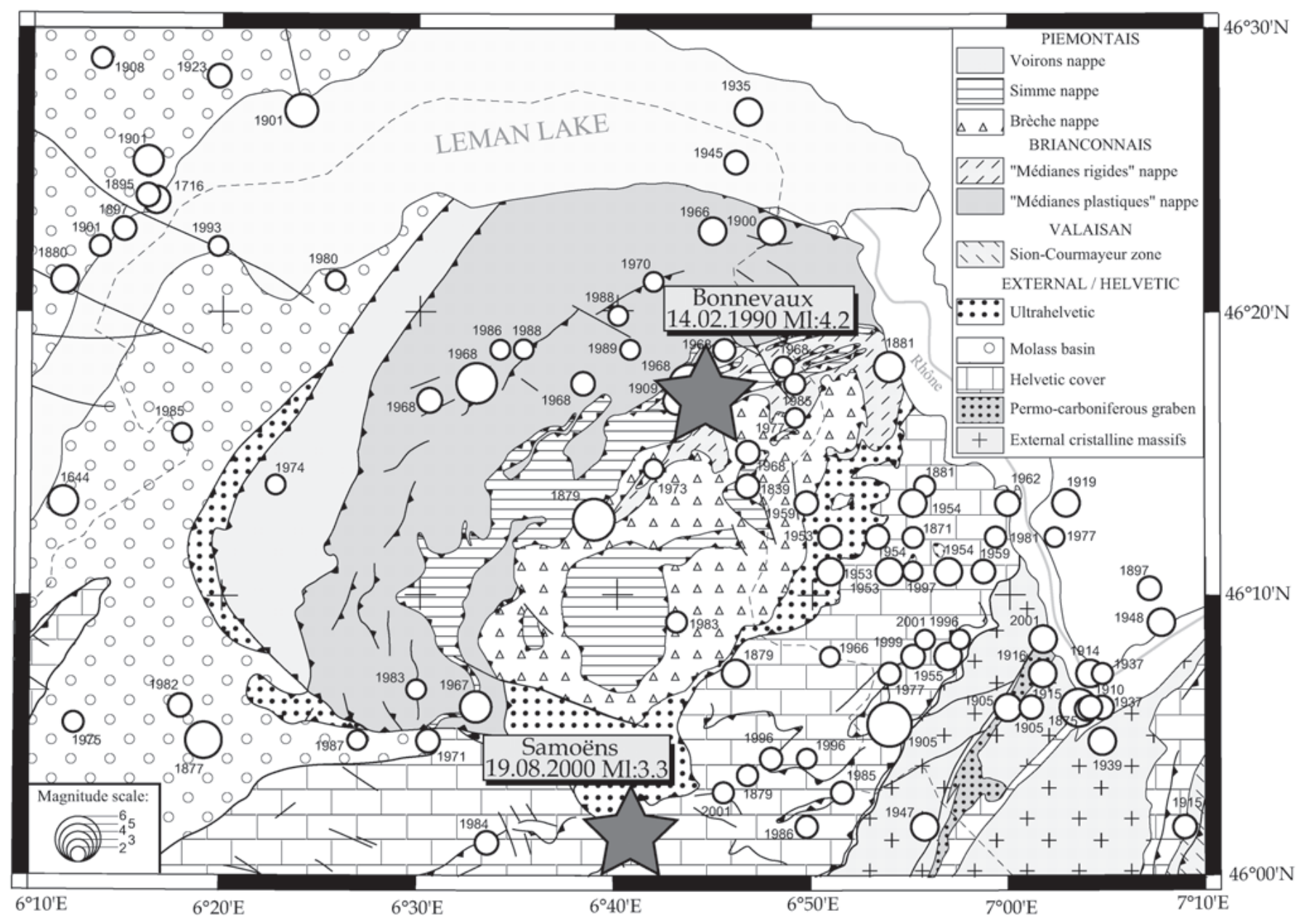

Fig. 1. Geology and seismicity of the Chablais area, with the locations of the Bonnevaux and Samoëns earthquakes analysed in this article. 


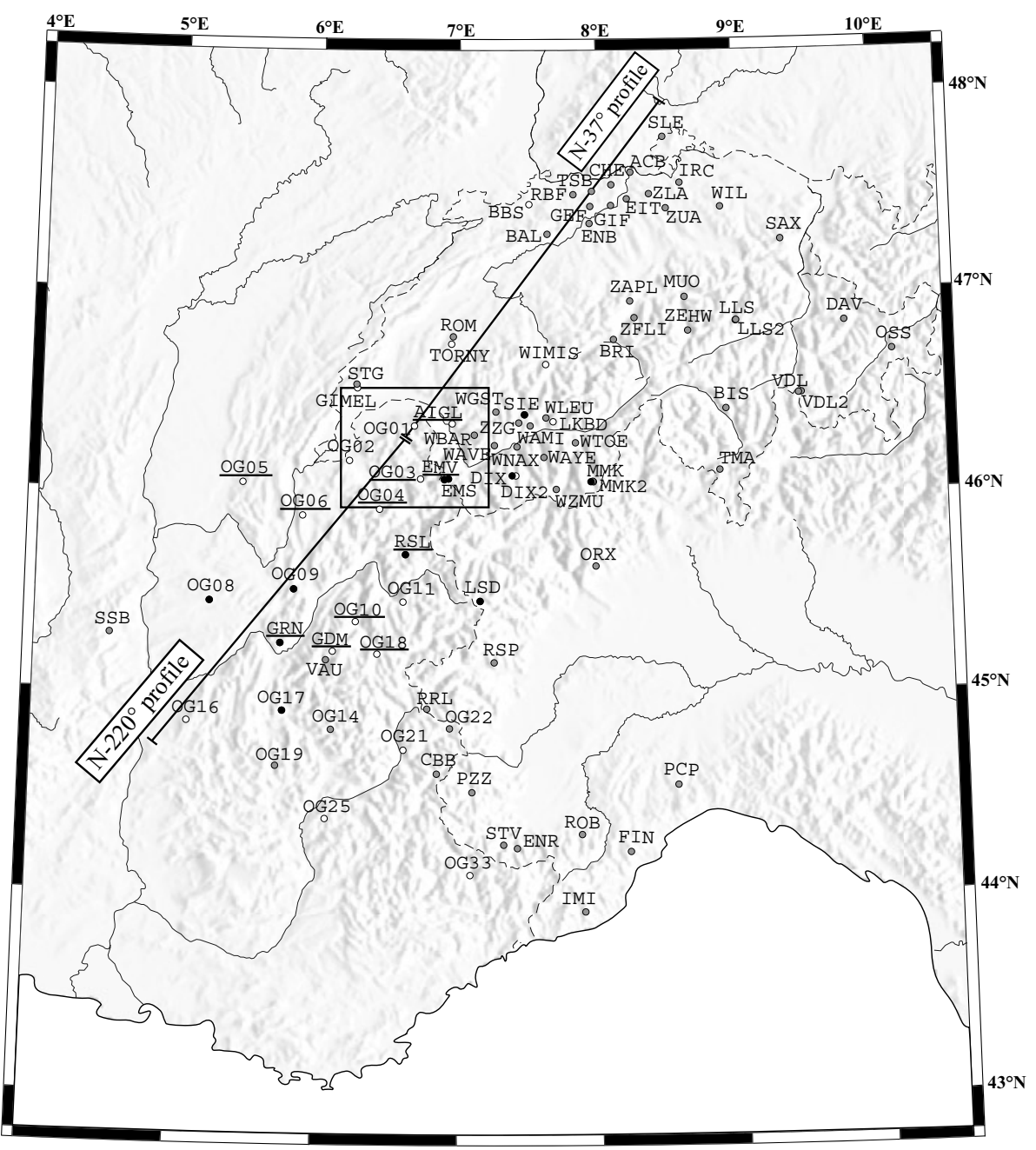

Fig. 2. Location of seismic stations used in this study. Grey dots: stations used for the study of the Bonnevaux earthquake. White dots: stations used for the study of the Samoëns earthquake. Black dots: stations used for both studies. Underlined station names: stations used for the cross-correlation study of the Samoëns seismic sequence. The rectangle delimits the area shown in Figure 1 and the straight lines correspond to the ray-trace profiles analysed in this study (see Fig. 3 for the diagram of the $\mathrm{N}-37^{\circ}$ profile). clear. The seismicity of the studied area (Fig. 1) is considered low to moderate, although several earthquakes have been felt by the population and are listed in the historical catalog (ECOS catalog, Swiss Seismological Service). Despite this well-documented seismicity, modern seismotectonic studies are still lacking, and the current tectonic setting and faulting of the Chablais region are still largely unresolved. In this study, we examine the current tectonic setting of the Chablais area by the seismotectonic analysis of the 1990 Bonnevaux earthquake and the 2000 Samoëns seismic sequence.

\section{Data analysis}

\section{The earthquake of Bonnevaux, 1990}

The Bonnevaux earthquake took place on February $14^{\text {th }} 1990$, at 15:56 (UTC), with a local magnitude (Ml) of 4.2 (Fig. 1). A preliminary location and focal mechanism have already been published by Maurer (1993). However, because of the lack of seismic stations at that time in the immediate vicinity of the epicenter (minimum distance is $26 \mathrm{~km}$ to station EMV, see Fig. 2) and because the routine location procedure is based on a $1 \mathrm{D}$ velocity model, both the focal depth and the take-off angles of the rays at the source are unreliable. As a consequence, the focal mechanism parameters given by Maurer (1993) are poorly constrained. Given the general lack of focal mechanisms in the Chablais region, a re-evaluation of this earthquake is important for constraining the local seismotectonic setting.

In this study, we complement the data base used by Maurer (1993) with additional data from stations in France and northern Italy, and apply 2-D ray-tracing to obtain improved estimates of the focal depth and take-off angles of the rays at the source. Given a 3-D model of the crust-mantle boundary (Moho), the focal depth can be constrained by comparing observed and calculated travel-time differences between the direct rays $(\mathrm{Pg})$ and the reflected $(\mathrm{PmP})$ or refracted rays $(\mathrm{Pn})$ at the Moho (e.g. Deichmann \& Rybach 1989; Eva et al. 1998). Seismograms of the Bonnevaux earthquake recorded at stations in northern Switzerland feature clearly identifiable Pn and Pg onsets. We have thus constructed a 2-D crustal model 


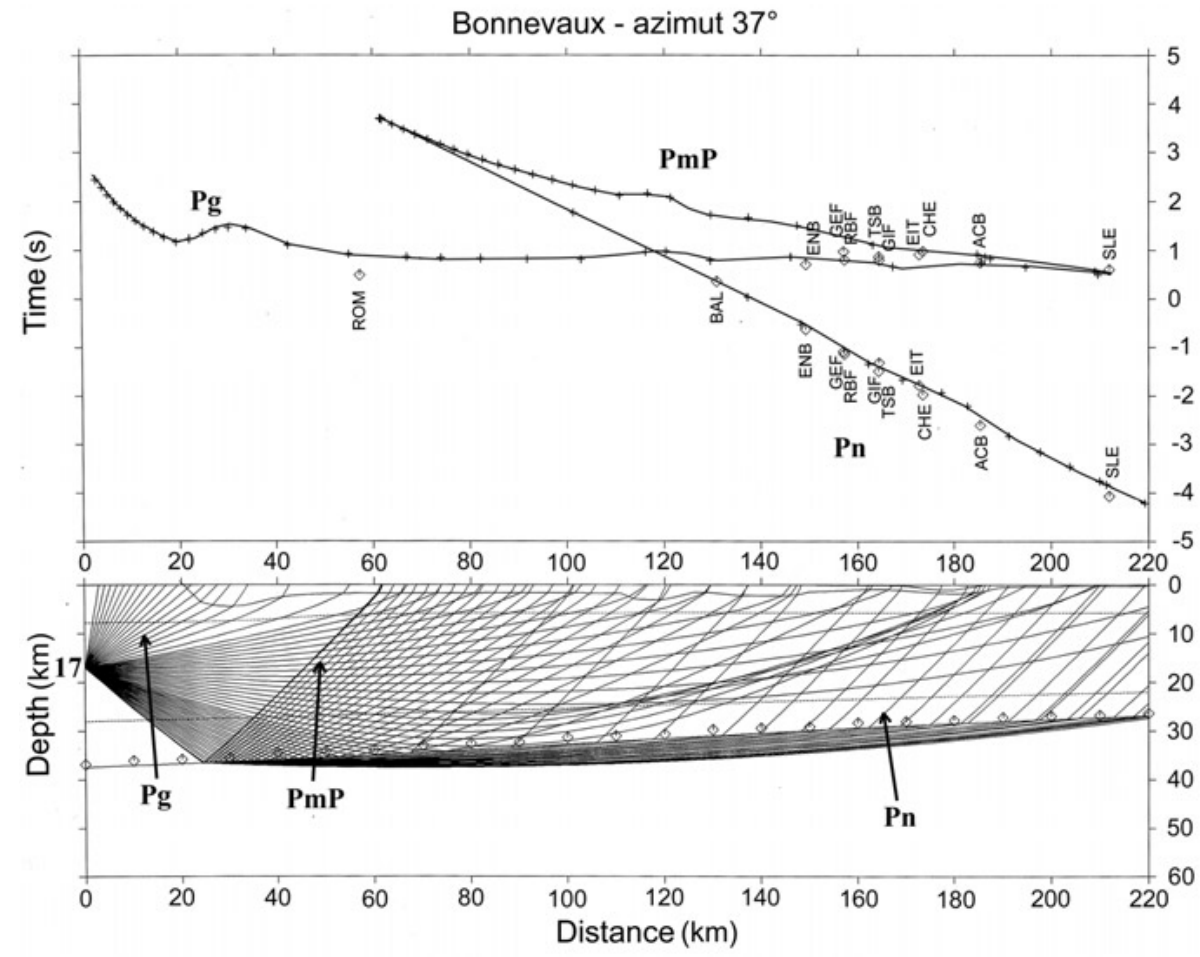

Fig. 3. Ray-trace diagram for the Bonnevaux earthquake in direction $\mathrm{N} 37^{\circ}$. Pg (direct), PmP (reflected from the Moho) and Pn (refracted at the Moho) phases are shown. The best-fit between observed (diamonds) and calculated travel times (black crosses) is obtained for a focal depth of $17 \mathrm{~km}$. in a $\mathrm{N} 37^{\circ}$ direction from the epicenter (Figs. 2 and 3) based on a model of the Moho topography by Waldhauser et al. (1998) and on $\mathrm{P}$-wave velocities obtained from various crustal refraction studies (Yan \& Mechie 1989; Maurer \& Ansorge 1992) and earthquake studies (Deichmann \& Rybach 1989; Pfister 1990; Maurer 1993). The ray-trace algorithm used was modified from Gebrande (1976). The best fit between the observed and calculated travel-time differences is obtained for a focal depth of 17 km (Fig. 3). Following Eva et al. (1998), we estimate the remaining depth uncertainty to be on the order of $+/$ 3-4 km. The resulting focal depth is thus somewhat greater than the $14 \mathrm{~km}$ given by Maurer (1993). Moreover, compared to the focal depths of the well-constrained earthquakes in the Valais (e.g. Maurer et al. 1997), which are concentrated in the upper $10 \mathrm{~km}$ of the crust, the hypocenter of the Bonnevaux event is unusually deep.

Focal mechanisms based on stereographic plots of first-motion polarities, in particular for dip-slip events, are especially sensitive to the correct identification of the corresponding phases and to a realistic estimate of the take-off angles of the rays at the source. For stations north of the epicenter of the Bonnevaux event we derived the take-off angles from the raytrace model in Figure 3. For stations in the south, we constructed a second ray-trace model along a profile towards Grenoble in a N220 direction. With 46 identifiable first-motion polarities evenly distributed around the source, and with only 3 inconsistent polarities, the focal mechanism is particularly well-constrained (Fig. 4). It corresponds to a strike-slip mechanism with either dextral slip on an ENE striking fault or sinistral slip on a NNW striking fault. The style of faulting thus differs significantly from the normal faulting mechanism proposed by Maurer (1993). However, the azimuth of the T-axis for the two mechanisms is practically the same (N34 ${ }^{\circ}$ vs. $\left.\mathrm{N} 27^{\circ}\right)$.

\section{The seismic sequence of Samoëns, 2000}

The mainshock of the earthquake sequence of Samoëns occurred on August 19th 2000 at 08:37 (UTC) with an Ml magnitude of 3.3 consistently computed both by SED and Sismalp. Six additional events with magnitudes between 1.5 and 2.4 and with almost identical signals were recorded during the following 10 days (Fig. 5) by both the Sismalp network of the University of Grenoble and by the network of the Swiss Seismological Service. Routine location procedures give a focal depth of $5 \mathrm{~km}$. Given the good azimuthal coverage $\left(\right.$ gap $\left.=103^{\circ}\right)$ and a station at an epicentral distance of only $5 \mathrm{~km}$ (OG03), this focal depth is reliable $( \pm 2 \mathrm{~km})$. This shows the importance of a dense seismological network (note that no Sismalp stations were operated in the Chablais area during the 1990 Bonnevaux earthquake).

As for the Bonnevaux event, the faultplane solution of the mainshock was constructed using take-off angles calculated by 2-D ray tracing. Given 34 identifiable first-motion polarities with an even azimuthal distribution, the result is a well-constrained strike-slip mechanism with N-S and E-W striking nodal planes and a NW-SE oriented P-axis (Fig. 6).

The striking waveform similarity of the different events shown in Figure 5 for station EMV and visible also at the other 


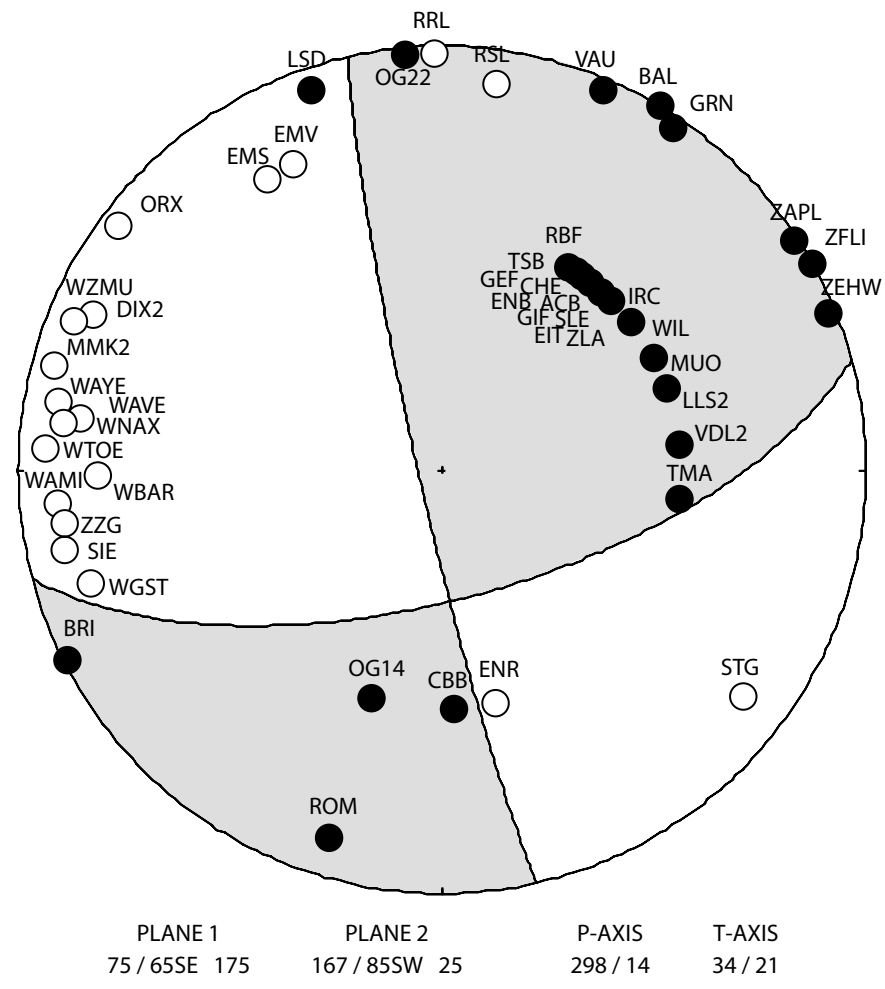

Fig. 4. Fault plane solution for the Bonnevaux earthquake (lower hemisphere equal area projection with black dots, positive first motions, and white dots, negative first motions). The focal mechanism parameters are given as strike, dip and rake of the two nodal planes and as azimuth and plunge of the P-and T-axis. stations demonstrates that the earthquakes in this sequence must all have similar source locations and the same focal mechanism. In fact, previous studies of such sequences of similar earthquakes have shown that their hypocenters lie on a common plane that closely coincides with one of the nodal planes of the common focal mechanism solution (e.g. Fréchet 1985; Logan 1987; Deichmann \& Garcia-Fernandez 1992; Augliera et al. 1995). By taking advantage of the signal similarity and applying a cross-correlation procedure in the time or frequency domain to the signals of pairs of events, one can resolve travel-time differences with a precision on the order of milliseconds (e.g. Fréchet 1985; Deichmann \& Garcia-Fernandez 1992; Augliera et al. 1995). Due to the nearly common ray path from each hypocenter to a given station, errors in the assumed seismic velocity model have no effect on the location of the events relative to each other, which can thus be determined with a precision of a few tens of meters.

To identify the active fault plane of the Samoëns cluster, we used the time-domain cross-correlation method of Deichmann \& Garcia-Fernandez (1992). This procedure calculates cross-correlations of $\mathrm{P}$ - or S-waves for all possible event pairs. Then the optimal arrival-time differences relative to a chosen master event are obtained through a least-squares adjustment of all the correlation results (Deichmann \& Garcia-Fernandez 1992). Examples of cross-correlations are shown in Figure 7. As master event we chose the seventh event in the sequence (Fig. 5), which had an intermediate magnitude (Ml 2.2) and thus a frequency content and waveform most similar to all

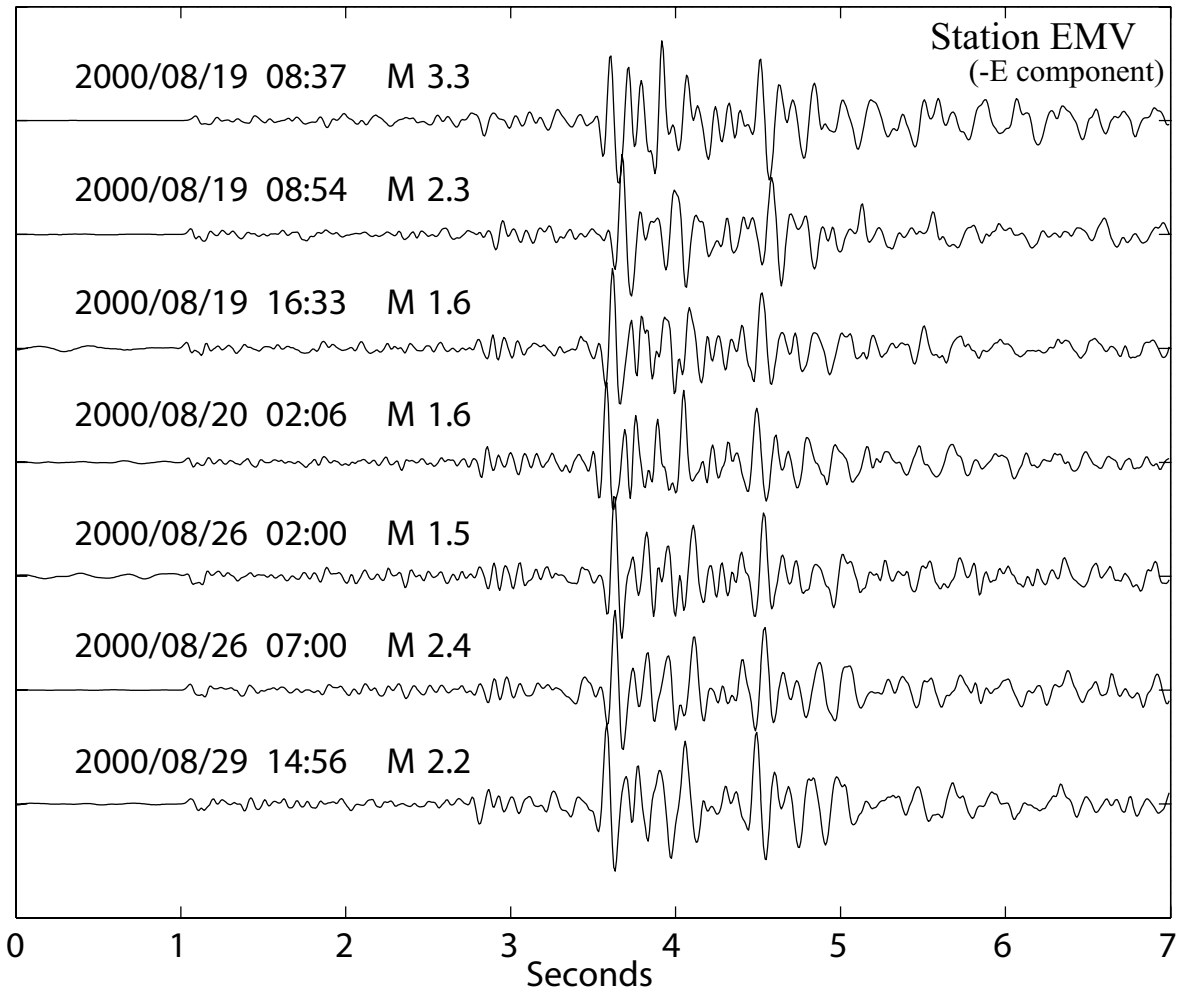

Fig. 5. Seismograms (EW component at station EMV) of the seven events of the Samoëns earthquake sequence for which relative locations have been determined (see Fig. 8). 


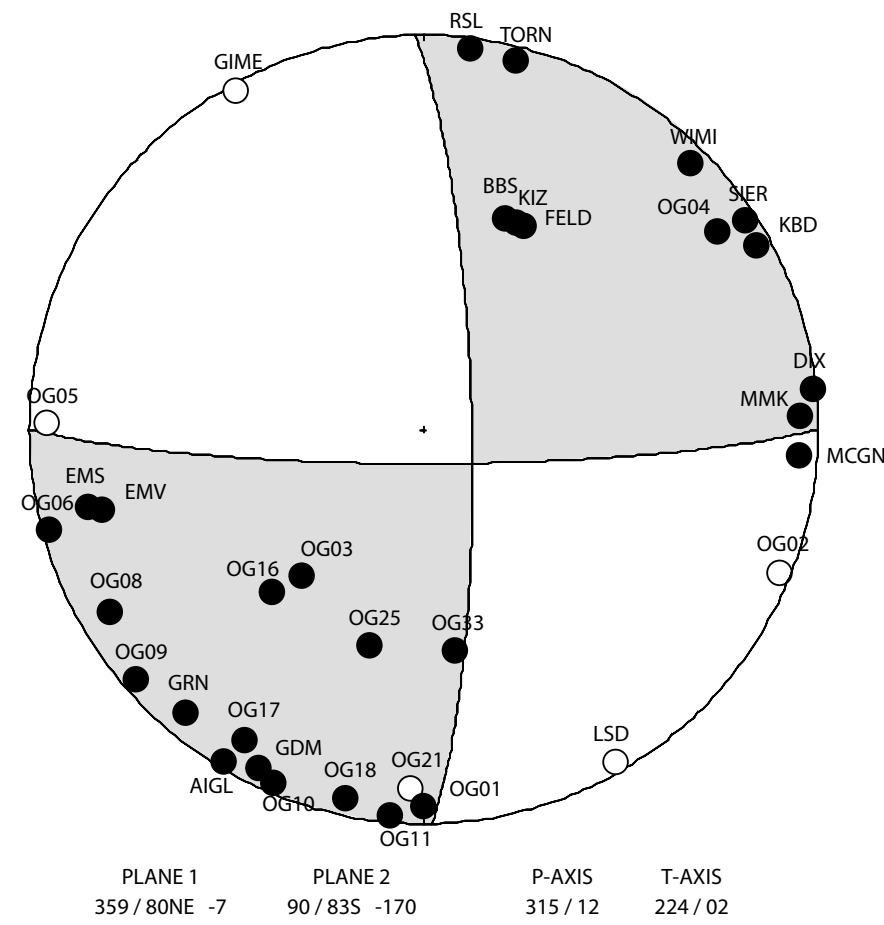

Fig. 6. Fault plane solution for the Samoëns mainshock (lower hemisphere equal area projection with black dots, positive first motions, and white dots, negative first motions). The focal mechanism parameters are given as strike, dip and rake of the two nodal planes and as azimuth and plunge of the P-and T-axis.

other events. From the arrival-time differences to our chosen master event we calculated the relative locations with the method proposed by Console \& Di Giovambattista (1987). This method is based on the assumption that the sources are located very close to each other compared to the distance to each station at which the signals are recorded. In this case, the take-off angles of the rays from each source to a given station can be regarded as constant, and the otherwise nonlinear location procedure reduces to a simple linear inversion problem. In addition to the arrival-time differences, the algorithm requires only the seismic velocities in the source region (to which it is not very sensitive) and the take-off angles at the source. The latter were estimated from 2-D ray-tracing. One advantage of this method is that one can also use arrival-time differences between PmP phases (in our case, recorded at station GRN), which can improve the precision of the relative focal depths significantly. The results of our relative location procedure, shown in Figure 8, demonstrate that the hypocenters of the Samoëns cluster indeed define a plane. The strike of this plane $\left(261^{\circ}\right)$ coincides to within less than $10^{\circ}$ and the $\operatorname{dip}\left(83^{\circ}\right)$ to within less than $20^{\circ}$ with the E-W striking nodal plane of the fault plane solution. We therefore conclude that the seismic sequence of Samoëns occurred as dextral slip on a steeply dipping more or less E-W striking fault at a depth of about $5 \mathrm{~km}$.
Despite its proximity to the external crystalline massif of the Aiguilles Rouges, the pre-Triassic basement is considered to lie at a depth of about $6 \mathrm{~km}$ in this region (Burkhard 1988). Given the remaining hypocentral uncertainty of $\pm 2 \mathrm{~km}$ and the $1.2 \mathrm{~km}$ vertical extent of the whole cluster, we can not determine whether the fault is located in the crystalline basement or in the Helvetic cover or whether it intersects the sedimentbasement transition.

\section{Discussion and tectonic interpretation}

In a region where the current active tectonics are still largely a matter of debate, our seismotectonic study provides some interesting new insights of active faulting in the Chablais area. The source of the Bonnevaux earthquake was located in the crystalline basement at a mid-crustal depth of about $17 \mathrm{~km}$. However, the Samoëns earthquake sequence, with a focal depth of $5 \mathrm{~km}$, could be located either in the crystalline basement or in the Helvetic cover; or it could also cross-cut the basement-sediment interface (hypothesis comforted by the $1.3 \mathrm{~km}$ extent of depth locations of the sequence). In both cases the focal mechanisms are transcurrent, with either dextral slip on a ENE striking fault or sinistral slip on a NNW striking fault in case of the Bonnevaux event, and with dextral slip on an E-W striking fault in case of the Samoëns sequence.

Previous seismotectonic studies in the Chablais area are few and contradictory. Whereas a normal focal mechanism (with a NE-SW oriented T-axis) has been computed by Ménard (1988) for an earthquake that occurred on August 19 1968 at Abondance (near Bonnevaux), a compressive mechanism (with a weak transcurrent component and a NW-SE oriented P-axis) is reported by Delouis et al. (1993) for the Cluses earthquake recorded on May $3^{\text {rd }} 1984$ just west of Samoëns. Given the low density of seismological networks operated at that time, the quality of the focal mechanism computed for the 1968 Abondance earthquake is questionable. However, this normal-faulting solution is consistent with the swarm activity observed there from June 1968 to January 1969, swarms being very often associated with normal faulting. It is also comparable to the focal mechanism proposed by Maurer (1993) for the 1990 Bonnevaux earthquake, but differs significantly from the revised strike-slip solution obtained in this study. In contrast to this strike-slip to normal faulting regime, the compressive mechanism computed by Delouis et al. (1993) for the 1984 Cluses earthquake is comparable to the one computed by Fréchet et al. (1996) for the Grand-Bornand earthquake (see Fig.9), which occurred on December $14^{\text {th }} 1994$ in the Bauges subalpine massif, and which was interpreted as a reactivation of a NE-SW oriented basement fault (late-Hercynian "Cévenoles" fault) under an E-W to ESE-WNW oriented direction of maximum shortening ( $\mathrm{P}$-axis).

Geomorphological studies in the Chablais area by Raymond et al. (1996) reveal some major alignments, possibly related to the neotectonic activity of this area. The two main 
Station EMV

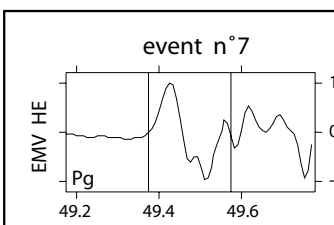

2000.08.29 14:56:49.376
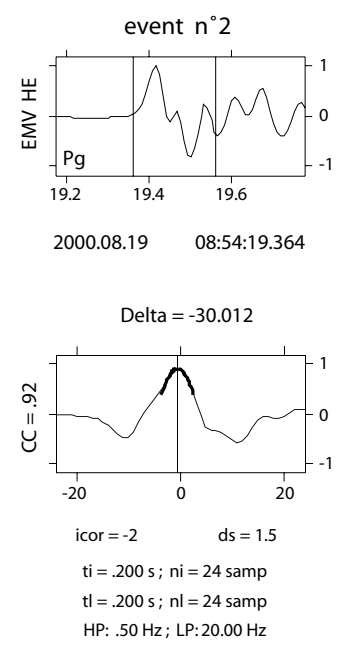

Station OG05

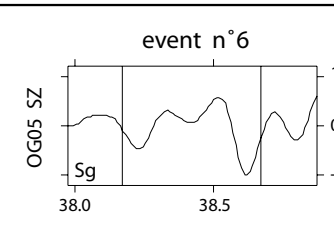

2000.08.26 07:00:38.173

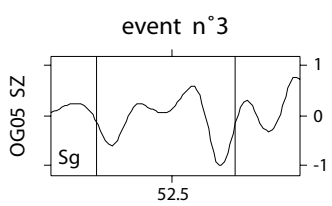

2000.08.19 16:33:52.226

Delta $=14.053$

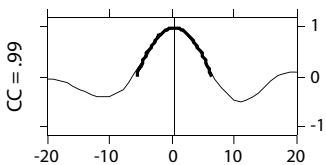

$\mathrm{icor}=-828 \quad \mathrm{ds}=3.3$

$\mathrm{ti}=.500 \mathrm{~s} ; \mathrm{ni}=50 \mathrm{samp}$

$\mathrm{tl}=.200 \mathrm{~s} ; \mathrm{nl}=20 \mathrm{samp}$

HP: $.50 \mathrm{~Hz} ; \mathrm{LP}: 8.00 \mathrm{~Hz}$
Station GRN

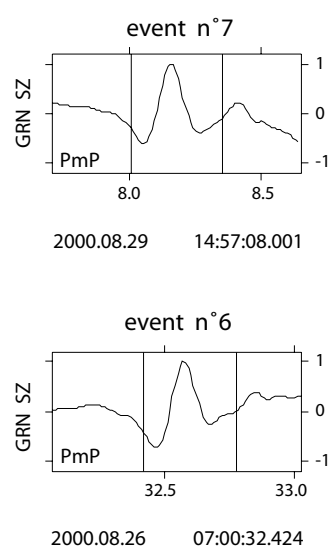

Delta $=24.423$

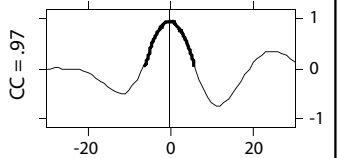

icor $=1663 \quad \mathrm{ds}=-5.2$

$\mathrm{ti}=.350 \mathrm{~s} ; \mathrm{ni}=35 \mathrm{samp}$

$\mathrm{tl}=.300 \mathrm{~s} ; \mathrm{nl}=30 \mathrm{samp}$

HP: $.50 \mathrm{~Hz} ;$ LP: $8.00 \mathrm{~Hz}$
Fig. 7. Examples of signal cross-correlations at stations EMV (Pg phase), OG05 (Sg phase) and GRN (PmP phase). The top two frames show the signals with the interval used for the correlation delimited by vertical bars. The lower frame shows the calculated cross-correlation function; to obtain a sub-sampling-interval resolution, the central maximum is interpolated with a second-order polynomial. Delta (in seconds) is the arrival-time difference used to calculate the relative locations: it corresponds to the time shift of the cross-correlation maximum (CC). The length of the time window (ti and ni), the maximum time shift (tl and $\mathrm{nl}$ ) and the filters are given at the bottom of each diagram. alignments are the $\mathrm{N}-10 / 20^{\circ}$ Bonnevaux fracture (see Fig. 9), defined by Badoux and Mercanton (1962) as a sinistral fault, and the $\mathrm{N}-125^{\circ}$ alignment, which runs from Bucheresse to Evian (see Fig. 9) and which corresponds to the southern extension of the Buchillon-Evian sinistral fault (Badoux \& Mercanton 1962). Raymond et al. (1996), on the basis of geological observations and geophysical data, conclude that the neotectonic activity associated with these alignments is governed by recent to present-day normal reactivation of these fractures, possibly associated with gravitational escape toward the $\mathrm{N}$ (following the downgoing topography towards Lake Leman). In comparison to the present seismotectonic study, the Bonnevaux alignment could correspond to the N-S sinistral nodal plane of the 1990 Bonnevaux focal mechanism. However, given the relatively large focal depth of this earthquake $(17 \mathrm{~km})$, a direct link to the surface morphology is unlikely. For the Bucheresse -Evian alignment, no equivalent is found in our seismotectonic analysis, but a subsurface gravity-driven extensional reactivation towards the N-NE, as proposed by Raymond et al. (1996), appears compatible with NE-SWoriented T-axes of the Bonnevaux and Samoëns focal mechanisms computed in this study.

On a larger scale, the current seismotectonic activity of the portion of the Alpine belt studied here is situated within the following framework (see Fig. 9):

- A conjugate transcurent regime dominates the Molasse Basin and the Jura mountains (Mosar \& Borel 1992; Thouvenot et al. 1998; Delacou et al. 2004; Kastrup et al. 2004).
This system, conjugate around compressive axes perpendicular to the Alpine trend (Delacou et al. 2004), progressively rotates anticlockwise from north to south, following the curvature of the Alpine belt. Thereby sinistral faults progressively rotate from a N-S direction in the northern Jura and Molasse Basin (e.g. seismic relative location alignment of Kastrup et al. (2004) near Fribourg, see Fig. 9) to a NW-SE direction in the southern Jura (Vuache fault seismic alignment of Thouvenot et al. (1998), see Fig. 9). Dextral faults belonging to this system and showing a current activity are rare, but many conjugate systems recognized in the field show large scale dextral faults that are supposedly potentially active (in a favourable orientation compared to the current stress field). Mosar and Borel (1992), on the basis of paleostress analyses in the "Préalpes Médianes" (Switzerland), conclude that a comparison of paleostress results from faults with results obtained from earthquake data in the Molasse Basin and the Jura mountains reveals striking similarities both in fault and stress orientations, with a strike-slip environment linked to large N-S trending vertical sinistral faults and $\mathrm{N}-110^{\circ}$ oriented dextral faults. However, these paleostress results concern the ancient faulting history and the current activity of this fault system remains uncertain.

- A compressive zone is associated with several compressive focal mechanisms in the Bauges massif area (Ménard 1988; Delouis et al. 1993; Delacou et al. 2004). No associated active compressive fault has been identified in this area, nor 

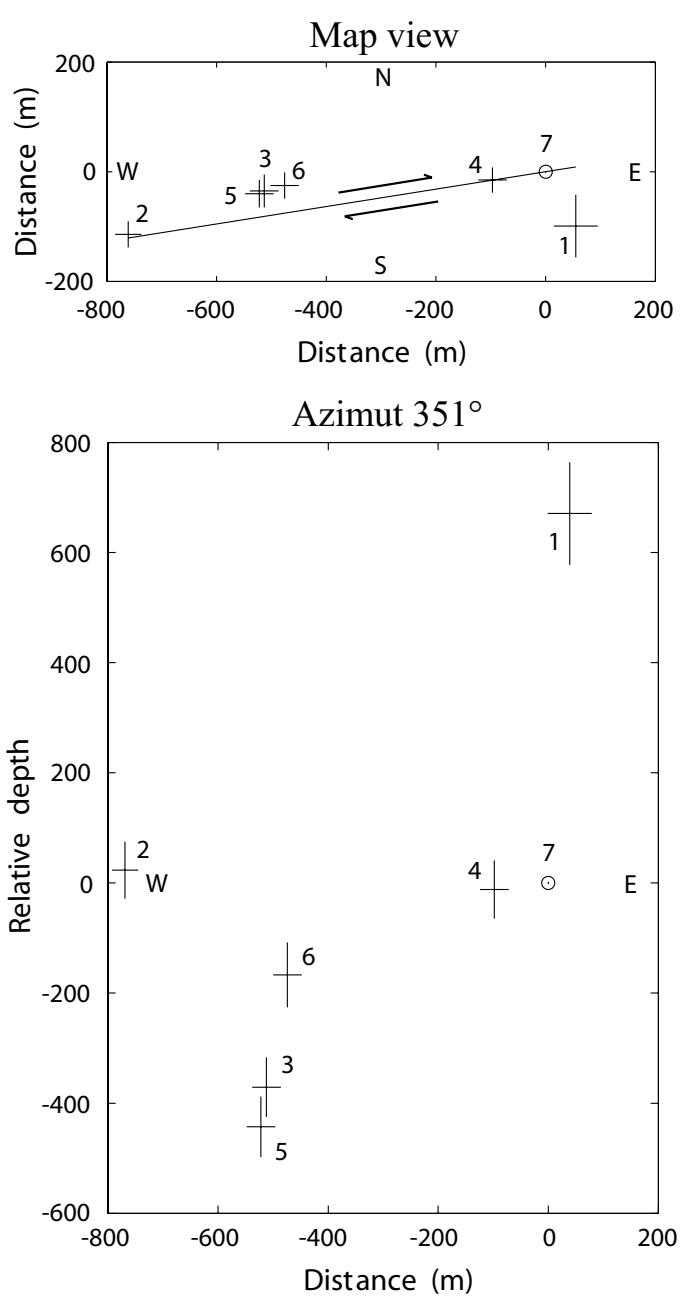
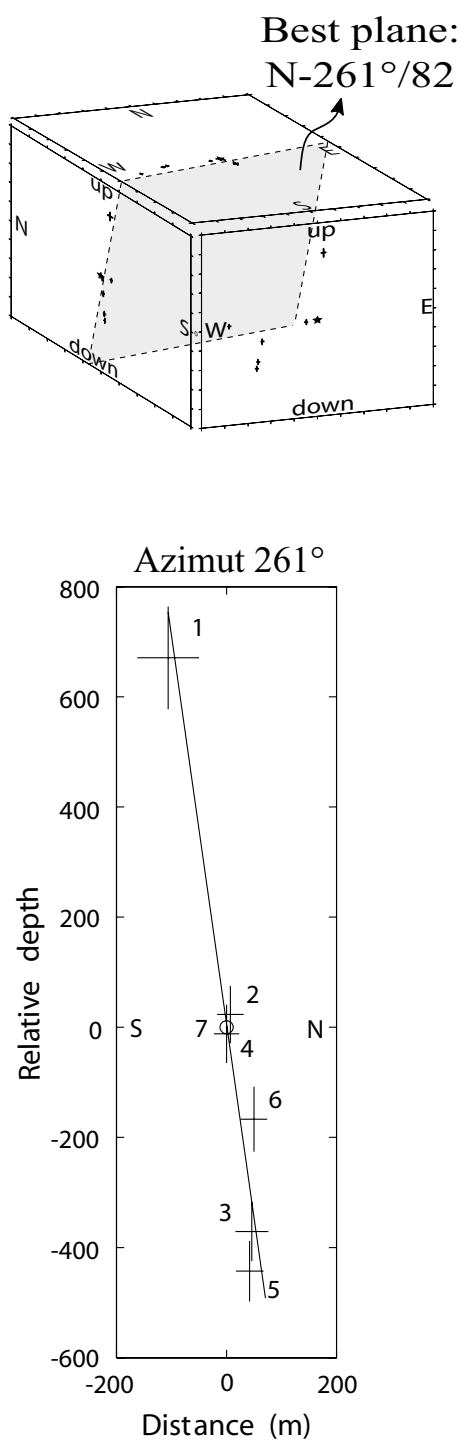

Fig. 8. Relative locations of the Samoëns seismic sequence with respect to the event $n^{\circ} 7$ (circle) calculated from the signal cross-correlations, in map view (top), cross-sections (left lower: E-W section (oriented $\mathrm{N}-351^{\circ}$ ), right lower: N-S section (oriented $\mathrm{N}-261^{\circ}$ )) and $3 \mathrm{D}$ view (right upper). The size of the crosses corresponds to one standard deviation of the location errors and the lines represent the trace of the best-fitting plane through the hypocenters $\left(261 / 83^{\circ}\right)$. by relative location nor by seismic alignments or neotectonic studies. Nevertheless, on the basis of the orientation of nodal planes of the 1994 Grand Bornand focal mechanism, Fréchet et al. (1996) conclude that NE-SW oriented basement faults should have controlled the slip associated with this earthquake. Actually, given a WNW-ESE to NWSE orientation of compressive axes in these zones (Delacou et al. 2004), NNE-SSW to NE-SW striking thrusts (see Fig. 9) would be optimally oriented.

- A dextral system, following the External Crystalline Massifs (ECM) alignment extends from the northern Valais (Wildhorn area) to Martigny. This transcurrent system, very well documented by the Wildhorn seismic alignment and associated relative locations (Maurer \& Deichmann 1995; Maurer et al. 1997) and by relative locations of the 2001 Martigny sequence (Deichmann et al. 2002), documents an exclusively dextral strike-slip regime that follows the local curvature of the Alpine arc. A possible continuation of this system to the south could be found in the dextral seismic alignment of the front of the Belledonne massif (Thouvenot et al. 2003) and, even further south, the High Durance/Argentera dextral fault system (Thouvenot 1996; Sue 1998; Sue et al. 1999; Sue \& Tricart 2003).

In this framework, the Chablais area appears to be geographically located just in between these three tectonic provinces (Fig. 9). However, the strike-slip focal mechanisms computed in this study appear to rely to the Molasse Basin/Jura transcurrent tectonic field, as the studied focal mechanisms are compatible with the conjugate system described in these areas, and are at a high angle with the strike of the dextral Wildhorn/Martigny alignment (Maurer \& Deichmann 1995; Maurer et al. 1997; Deichmann et al. 2002). These results confirm the conclusions of Mosar and Borel (1992) regarding 


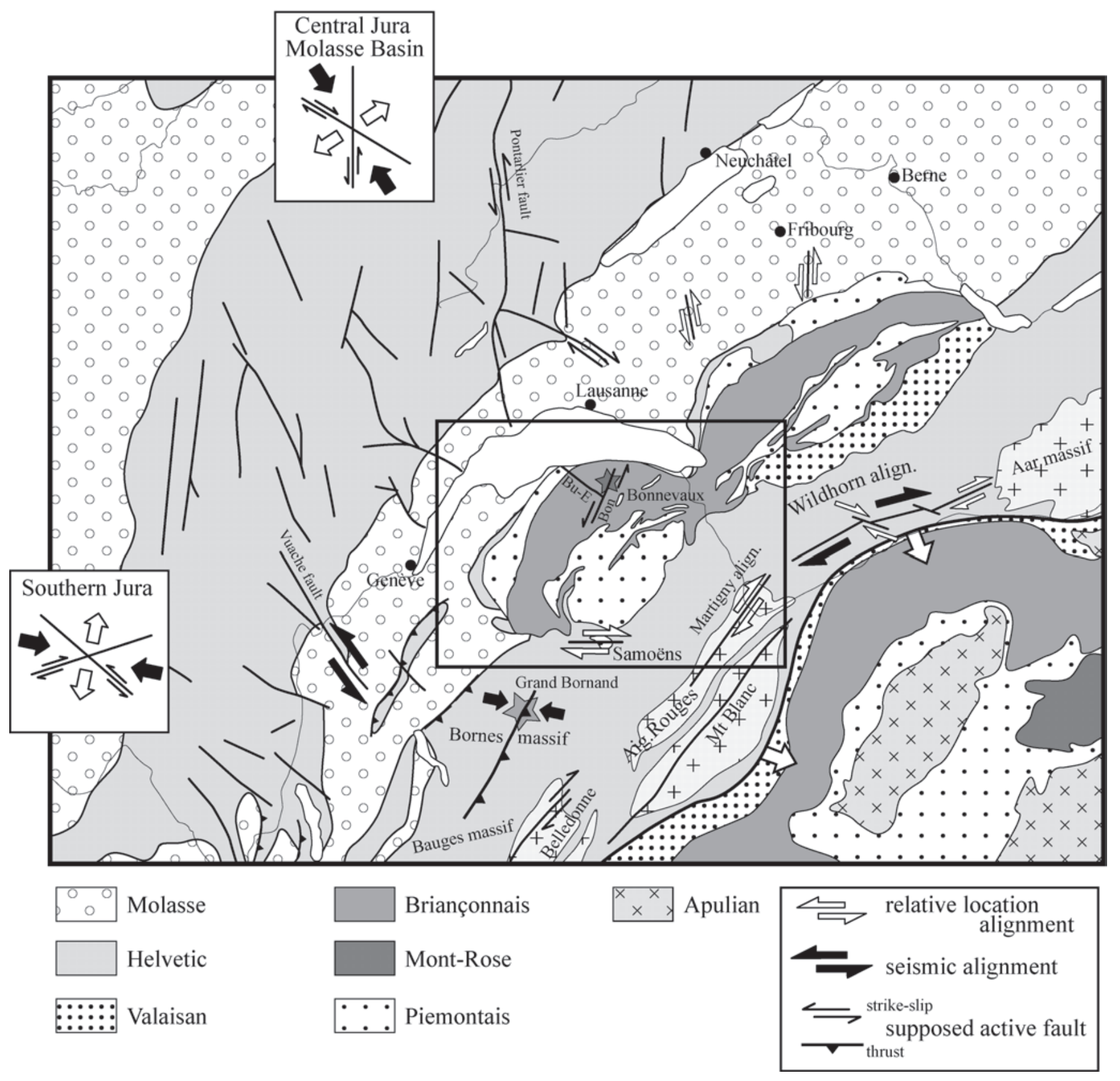

Fig. 9. Active faulting of the NW Alps synthesized from (Maurer \& Deichmann 1995; Fréchet et al. 1996; Raymond et al. 1996; Thouvenot et al. 1998; Delacou et al. 2004; Kastrup et al. 2004). Two sketches (top and left) schematize the strike-slip regimes belonging to the Central Jura/Molasse Basin and Southern Jura tectonic provinces (see text for more details). The rectangle delimits the area shown in Figure 1. Grey stars represent the location of the 1994 Grand Bornand (associated to black arrows representing the P-axis orientation) and 1990 Bonnevaux earthquakes. In the Bonnevaux area, neotectonic alignments of Raymond et al. (1996) are represented (Bu-E: Bucheresse-Evian lineament, Bon: Bonnevaux lineament). The sinistral N-10 oriented Bonnevaux lineament could be associated to the N-S oriented nodal plane of the computed 1990 Bonnevaux focal mechanism.

the Swiss part of the Prealpes on the basis of paleostress analyses. The studied earthquakes show that the Chablais area, despite its geographical proximity to the Wildhorn/ Martigny area, belongs to the external Molass Basin/Jura tectonic province.

\section{Conclusions}

In a region where the geological and tectonic history is as complex as in the Prealpes, the study of the current tectonic activity should represent the basis for the understanding of the re- 
cent evolution of this part of the Alpine belt. Seismotectonics, analysing the present-day seismicity, represents a powerful tool to identify active faulting and to define the current regime of deformation. The relative location of earthquakes belonging to a seismic sequence and activating a single fault represents the best way to identify active faults, especially in a region where evidence of neotectonic activity is scarce (e.g. Badoux \& Mercanton 1962; Raymond et al. 1996). Our study of the 1990 Bonnevaux and 2000 Samoëns earthquakes in the Chablais area enable the recognition of a transcurrent faulting regime (Figs. 4 and 5) with NW-SE oriented P-axes. The precise relative location analysis of 7 earthquakes belonging to the Samoëns seismic sequence permits the identification of an E-W oriented subvertical fault (Fig. 7 and 8) which corresponds to the E-W dextral nodal plane of the focal mechanism of the main shock.

This evidence, together with a comparison to the seismotectonic regime of adjacent parts of the Alpine belt (Fig. 9), shows that the Chablais area belongs to the larger scale transcurrent regime that prevails in the external zone of the Molasse Basin and the Jura mountains, a regime characterized by conjuguate strike-slip faults, associated with orogen-perpendicular P-axes progressively rotating with the curvature of the Alpine arc. This system contrasts with the exclusively dextral transcurrent regime of the Wildhorn/Martigny region, characterize by faults striking parallel to the alignment of the External Crystalline Massifs.

\section{Acknowledgements}

This study was supported by Neuchâtel University and the Swiss National Science Foundation (grants \# 21-61684.00 and \# 200020-101625/1). We thank J. Mosar and W. Brüstle for constructive reviews and comments.

\section{REFERENCES}

Augliera, P., Cattaneo, M., Eva, C. 1995: Seimic multiplets analysis and its implication in seismotectonics. Tectonophysics 248, 219-234.

Badoux, H., Mercanton, C. H. 1962: Essai sur l'évolution tectonique des Préalpes du Chablais. Eclogae geol. Helv. 55, 135-188.

BAUD, A. 1972: Observations et hypothèses sur la géologie de la partie radicale des Préalpes médianes. Eclogae geol. Helv. 65(1), 43-55.

Borel, G. D., Mosar, J. 2000: Subsurface structures in the Chablais Prealpes: New tectonic interpretations of the Prealpes Medianes nappe based on palinspastic lengths. Eclogae geol. Helv. 93(3), 307-314.

Burkhard, M. 1986: Déformation des calcaires de l'Helvétique de la Suisse occidentale (Phénomènes, mécanismes et interprétations tectoniques) Revue de Géologie Dynamique et de Géographie Physique 27(5), 281301.

BurKHARD, M. 1988: L'helvétique de la bordure occidentale du massif de l'Aar (évolution tectonique et métamorphique). Eclogae geol. Helv. 81, 63-114.

Burkhard, M., Sommaruga, A. (1998). Evolution of the western Swiss Molasse basin: structural relations with the Alps and the Jura belt. In: Cenozoic Foreland Basins of Western Europe. Eds: A. Mascles, C. Puigdefàbregas, H. P. Luterbacher And M. FernàndeZ. Geological Society Special Publication, London, 134.

Console, R., Di Giovambattista, R. 1987: Local earthquake relative location by digital records. Phys. Earth Planet. Inter. 47, 43-49.
Deichmann, N., Baer, M., Braunmiller, J., Ballarin Dolfin, D., Bay, F., Bernardi, F., Delouis, B., Fäh, D., Gerstenberger, M., Giardini, D., Huber, S., Kradolfer, M., Maraini, S., Oprsal, I., Schibler, R., Schler, T., Sellami, S., Steimen, S., Wiemer, S., Wössner, J., Wyss, A. 2002: Earthquakes in Switzerland and surrounding region during 2001. Eclogae geol. Helv. 95, 249-261.

Deichmann, N., Garcia-Fernandez, M. 1992: Rupture geometry from highprecision relative hypocenter locations of microearthquakes clusters. Geophys. J. Int. 110, 501-517.

DeichmanN, N., RyBaCH, L. 1989: Earthquakes and temperatures in the lower crust below the Northern Alpine Foreland of Switzerland. Geophysical Monograph 51(6), 197-213.

Delacou, B., Sue, C., Champagnac, J. D., Burkhard, M. 2004: Present-day geodynamics in the bend of the western and central Alps as constrained by earthquake analysis. Geophys. J. Int. 158, 753-774.

Delouis, B., Haessler, H., Cisternas, A., Rivera, L. 1993: Stress Tensor Determination in France and Neighboring Regions. Tectonophysics 221(3-4), 413-438.

Escher, A., Hunziker, J. C., Marthaler, M., Masson, H., Sartori, M., STECK, A. 1997: Geological framework and structural evolution of the Western Swiss-Italian Alps. In: Deep structures of the Swiss Alps: results of NRP20. Eds: O. A. Pfiffner, P. Lehner, P. Heitzmann, S. Mueller and A. STECK. Birkhäuser Verlag, Basel, Boston, Berlin, 205-222.

Eva, E., Pastore, S., Deichmann, N. 1998: Evidence for ongoing extensional deformation in the Western Swiss Alps and thrust-faulting in the southwestern Alpine foreland. J. Geodyn. 26(1), 27-43.

FrÉCHET, J. 1985: Sismogénèse et doublets sismiques. Thèse de doctorat. Université de Grenoble. Grenoble.

Fréchet, J., Thouvenot, F., Jenatton, L., Hoang-Trong, P., Frogneux, M. 1996: Le séisme du Grand-Bornand (Haute-Savoie) du 14 décembre 1994: un coulissage dextre dans le socle subalpin. C. R. Acad. Sci. Paris 323(IIa), 517-524.

Gebrande, H. (1976). A seismic-ray tracing method for two-dimensional inhomogeneous media. In: Explosion Seismology in Central Europe. Eds: P. Giese, C. Prodehl and A. Stein. Springer-Verlag, Berlin, 162-167.

JABOYedoff, M., CoscA, M. A. 1999: Dating incipient metamorphism using 40Ar/39Ar geochronology and XRD modeling: a case study from the Swiss Alps. Contrib. Mineral. Petrol. 135, 93-113.

Kastrup, U., Zoback, M. L., Deichmann, N., Evans, K., Giardini, D. 2004 Stress field variations in the Swiss Alps and the northern Alpine foreland derived from inversion of fault plane solutions. J. Geophys. Res. 109(B01402).

LogAn, A. L. L. 1987: Accurate Relative Location of Similar Earthquakes. Ph.D. thesis. University of Edinburgh.

LugEOn, M., GAGNEBIn, E. 1941: Observations et vues nouvelles sur la géologie des Préalpes romandes. Bulletin des Laboratoires de Géologie, Minéralogie, Géophysique et du Musée Géologique de l'Université de Lausanne 72, 1-90.

MAURER, H. 1993: Seismotectonics and upper crustal structure in the Western Swiss Alps. Ph.D. thesis. ETH Zürich. 159pp.

Maurer, H., Ansorge, J. 1992: Crustal structure beneath the northern margin of the Swiss Alps. Tectonophysics 207, 165-181.

Maurer, H., Burkhard, M., Deichmann, N., Green, G. 1997: Active tectonism in the central Alps: Contrasting stress regimes north and south of the Rhone Valley. Terra Nova 9, 91-94.

Maurer, H., DeichmanN, N. 1995: Microearthquake cluster detection based on waveform similarities, with an application to the western Swiss Alps. Geophys. J. Int. 123, 588-600.

MÉnARD, G. 1988: Structure et cinématique d'une chaîne de collision: Les Alpes occidentales et centrales. Thèse de Doctorat d'état. Université Joseph Fourier. 278pp., Grenoble.

Mosar, J. 1988: Métamorphisme transporté dans les Préalpes. Schweiz. mineral. petrogr. Mitt. 68, 77-94.

Mosar, J. 1997: Folds and thrusts in the Préalps Médianes Plastiques Romandes. Bulletin de la Société Vaudoise de Sciences Naturelles 84(4), 347-384.

Mosar, J. 1999: Present-day and future tectonic underplating in the western Swiss Alps: reconciliation of basement/wrench-faulting and decollement folding of the Jura and Molasse basin in the Alpine foreland. Earth Planet. Sci. Lett. 173(3), 143-155. 
Mosar, J., Borel, G. 1992: Paleostress from the Préalpes Médianes (Switzerland). Ann. Tecto. 6(2), 115-133.

Mosar, J., Stampfli, G. M., Girod, F. 1996: Western Prealpes Medianes Romandes: Timing and structure. A review. Eclogae geol. Helv. 89(1), 389-425.

PFISTER, M. 1990: Gemeinsame Auswertung von Erdbeben-, Refraktions- und Reflexions- daten in der Nordschweiz. Unpublished diploma thesis. ETHZ, Institute of Geophysics. Zürich.

Raymond, D., Deffontaines, B., Ferhi, A., Dorioz, J. M., Rudant, J. P. 1996: Neotectonic of the south Lemanic area (E-France): A multisource approach (optical images and radar, morphologic analysis). Eclogae geol. Helv. 89(3), 949-973.

SCHARDT, H. 1894: Sur l'origine des Préalpes romandes (zone du Chablais et du Stockhorn). Eclogae geol. Helv. 4, 129-142.

SCHARDT, H. 1898: Les régions exotiques du versant Nord des Alpes Suisses. Préalpes du Chablais et du Stockhorn et les Klippes. Bulletin de la Société Vaudoise de Sciences Naturelles 34, 113-219.

SuE, C. 1998: Dynamique actuelle et récente des Alpes occidentales internes Approche structurale et sismologique. Thèse de doctorat. Université Joseph Fourier. 299pp., Grenoble.

Sue, C., Thouvenot, F., Frechet, J., Tricart, P. 1999: Widespread extension in the core of the western Alps revealed by earthquake analysis. J. Geophys. Res. 104(B11), 25611-25622.

Sue, C., Tricart, P. 2003: Neogene to current normal faulting in the inner western Alps: a major evolution of the late alpine tectonics. Tectonics 22(5).
Thouvenot, F. 1996: Aspects géophysiques et structuraux des Alpes occidentales et de trois autres orogénèses (Atlas, Pyrénées, Oural). Thèse de doctorat d'Etat. Université Joseph Fourier. 378pp., Grenoble.

Thouvenot, F., Frechet, J., Jenatton, L., Gamond, J. F. 2003: The Belledonne Border Fault: Identification of active seismic strike-slip fault in the western Alps. Geophys. J. Int. 155(1), 174-192.

Thouvenot, F., Frechet, J., Tapponnier, P., Thomas, J. C., Le Brun, B., Menard, G., Lacassin, R., Jenatton, L., Grasso, J. R., Coutant, O., Paul, A., HatzFeld, D. 1998: The Ml 5.3 Epagny (French Alps) earthquake of 1996 July 15: a long-awaited event on the Vuache Fault. Geophys. J. Int. 135(3), 876-892.

Waldhauser, F., Kissling, E., Ansorge, J., Mueller, S. 1998: Three-dimensional interface modelling with two-dimensional seimic data: the Alpine crust-mantle boundary. Geophys. J. Int. 135, 264-278.

Wissing, S., Pfiffner, A. 2002: Structure of the eastern Klippen nappe (BE, FR): Implications for its Alpine tectonic evolution. Eclogae geol. Helv. 95, 381-398.

YAN, Q. Z., MeChIE, J. 1989: A fine structural section through the crust and lower lithosphere along the axial region of the Alps. Geophys. J. Int. 98, $465-488$.

Manuscript received February 5, 2005

Revision accepted August 14, 2005

Published Online First November 23, 2005 
